\title{
Genetic variation in prairie populations of Melanoplus sanguinipes, the migratory grasshopper
}

\author{
W. Chapco and M. J. Bidochka
}

Department of Biology, University of Regina, Regina, Saskatchewan, Canada S4S 0A2.

Genetic variation at two visible loci and 10 electrophoretic loci in populations of the migratory grasshopper, Melanoplus sanguinipes, in the Canadian prairies is described. Tibia colour and femoral stripe loci exhibit considerable geographic variation in frequency. Multiple regression and correlation analyses revealed clinal variation patterns for tibia colour, with minimum annual temperature accounting for about $\mathbf{4 0}$ per cent of that variation. The possible direct and indirect effects of this factor are discussed. No spatial patterns were evinced for the femoral stripe locus despite its close linkage to the tibia colour gene. Whatever the nature of selection, coefficients must be large enough to maintain polymorphism and divergence in opposition to the swamping effects of gene flow. This does not appear to be the case for the allozyme loci; frequencies of the most common allele at each locus are high (average heterozygosity $=4.5$ per cent) and about the same at each location. The mean level of polymorphism, 37.8 per cent, is well within the range of most insects.

The migratory grasshopper, Melanoplus sanguinipes (formerly known as M. bilituratus, M. mexicanus and M. atlantis-see Gurney, 1962), is widely distributed throughout North America, occupying (particularly sandy aspects of) a variety of habitats such as grasslands, roadsides, open areas in forests and even northern tundra (Vickery and Kevan, 1983). This, in part, is attributable to the insect's polyphagia (Mulkern et al., 1969; Vickery and Kevan, 1983) and reported capacity to migrate over long distances (Parker et al., 1955; Johnson, 1969; Vickery and Kevan, 1983). Given these features one might, therefore, expect the species to be fairly rich genetically depending on the amount of gene flow. Migratory proclivities need not be translated into gene flow effects (Endler, 1977), but in $M$. sanguinipes, at least, there is good evidence from past records of outbreak periods that migrating females do deposit eggs contributing to the next year's pullulation (Parker et al., 1955). Also based on historical accounts, it is reasonable to assume that the current population structure was engendered by the development of agriculture on the prairies over a century ago, settlement and cultivation providing both suitable pod laying sites and succulent food (Bird, 1961; Roffey, 1970; Turnock, 1977). M. sanguinipes was probably spottily distributed prior to the transition to an agricultural ecosystem, which according to many (e.g., Roffey, 1970; Turnock, 1977) coincided with-some say caused-the extinction of the most destructive grasshopper in North America, the Rocky Mountain grasshopper, $M$. spretus. During this century, $M$. sanguinipes has enjoyed, at irregular intervals, massive outbreaks in numbers, which today can be predicted largely on the basis of climatic conditions (Gage et al., 1976; Gage and Mukerji, 1977). As is typical for most members of the Orthopteran order, information on the population genetics of $M$. sanguinipes is patchy (Chapco, $1983 \mathrm{~b})$. While there is certainly no shortage of reports on phenotypic variability for this species (Shotwell, 1930; Gurney and Brooks, 1959), until recently only the polymorphism, in hind tibia colour (red versus blue), has been genetically researched (King and Slifer, 1955; the locus was labelled $T$ by Chapco, 1980a). Brooks' (1958) classification and Gurney and Brooks' (1959) monograph on the genus Melanoplus give several qualitative accounts of the geographical distribution of tibia colour variants. In Canada, the red form is predominant in Quebec, Ontario, British Columbia and the prairie parklands (the "more humid part"), whereas the blue form is predominant in the prairie grasslands. No distribution maps are provided, although Brooks (1958) does 
state that the blue form is "usually confined to a narrow strip south of a line from Medicine Hat, Alta. to Brandon, Man., but after a series of 'good' grasshopper years, or in local dry spots, this form predominates on the grasslands". Based on rearing studies, Brett (1947) claimed that high humidity and high temperature (also the consuming of lettuce and corn) "produce" a preponderance of individuals with red caudal tibiae. The results are taken as experimental confirmation of Hebard's (1925) assertion that in South Dakota, the red forms are more frequent in the "more humid sections of the state; elsewhere in more arid areas, hind tibiae are mostly glaucous". Brett's experiments, unfortunately, are difficult to evaluate since information on source of material, and in some cases, sample sizes, and proper controls are lacking.

In a preliminary survey of several North American populations, it was shown that from Quebec to Saskatchewan, the frequency of the red tibia allele $\left(T^{\mathrm{R}}\right)$ decreases with about a three-fold drop occurring from the Manitoba-Saskatchewan border near Ebenezer $\left(51^{\circ} 22^{\prime}, 102^{\circ} 27^{\prime}\right)$, located in the aspen-parkland to Regina $\left(50^{\circ} 25^{\prime}, 104^{\circ} 35^{\prime}\right)$, located in the grassland area (Chapco, 1983a). Since no material was obtained between these two points, it is not known whether the changes are abrupt or smooth. Also examined were the distributions of three other traits whose genetics have previously been worked out: red back (Pro locus), femoral stripe (Ost locus) and lactate dehydrogenase ( $L d h$ locus) (Chapco, 1980a; 1980b; 1984). Ost exhibits considerable geographical variation; Pro is uniformly rare everywhere; and the most common $L d h$ allele is uniformly frequent in all sampled areas.

The present study concentrates on the southern Saskatchewan area in order to (a) establish the nature of the $T^{\mathrm{R}}$ cline, (b) test statistically the hypothesis, suggested by the literature, that the distribution of $T^{\mathrm{R}}$ is connected to moisture and

Table 1 Red tibia colour and femoral stripe allelic frequencies at 32 prairie locations

\begin{tabular}{|c|c|c|c|c|c|}
\hline Locality & $\begin{array}{l}\text { Latitude } \\
\text { ( }{ }^{\circ} \text { North) }\end{array}$ & $\begin{array}{c}\text { Longitude } \\
\text { ( }{ }^{\circ} \text { West) }\end{array}$ & $\mathrm{N}$ & $\% T^{\mathrm{R}}$ & $\%$ Ost \\
\hline 1. Carnduff & $49 \cdot 17$ & $101 \cdot 83$ & 254 & 14 & 53 \\
\hline 2. Oxbow & $49 \cdot 23$ & $102 \cdot 18$ & 115 & 13 & 56 \\
\hline 3. Mankota* & $49 \cdot 42$ & 107.07 & 74 & 11 & 28 \\
\hline 4. Pangman & $49 \cdot 65$ & $104 \cdot 63$ & 111 & 13 & 62 \\
\hline 5. Kayville & $49 \cdot 73$ & $105 \cdot 17$ & 42 & 20 & 65 \\
\hline 6. Assiniboia* & $49 \cdot 63$ & $105 \cdot 98$ & 125 & 12 & 38 \\
\hline 7. Ormiston* & $49 \cdot 75$ & $105 \cdot 37$ & 185 & 12 & 69 \\
\hline 8. Bateman & $50 \cdot 02$ & $106 \cdot 75$ & 71 & 12 & 71 \\
\hline 9. Gull Lake & $50 \cdot 13$ & $108 \cdot 45$ & 78 & 12 & 58 \\
\hline 10. Rowatt & $50 \cdot 33$ & $104 \cdot 62$ & 184 & 11 & 38 \\
\hline 11. Whitewood & $50 \cdot 33$ & $104 \cdot 25$ & 106 & 25 & 60 \\
\hline 12. Jameson* & $50 \cdot 42$ & $102 \cdot 28$ & 104 & 19 & 33 \\
\hline 13. Grenfell & $50 \cdot 42$ & $102 \cdot 93$ & 100 & 31 & 65 \\
\hline 14. Indian Head* & $50 \cdot 53$ & 103.67 & 148 & 16 & 33 \\
\hline 15. Stockhoim & $50 \cdot 67$ & $102 \cdot 25$ & 51 & 20 & 72 \\
\hline 16. Keeler & $50 \cdot 70$ & $105 \cdot 85$ & 55 & 16 & 44 \\
\hline 17. Bethune & $50 \cdot 72$ & $105 \cdot 13$ & 186 & 12 & 44 \\
\hline 18. Russell & $50 \cdot 77$ & $101 \cdot 28$ & 48 & 25 & 62 \\
\hline 19. Tugaske & $50 \cdot 88$ & $106 \cdot 27$ & 173 & 13 & 59 \\
\hline 20. Melville* & 50.92 & $102 \cdot 80$ & 55 & 44 & 34 \\
\hline 21. Craik & $51 \cdot 05$ & $105 \cdot 82$ & 80 & 8 & 45 \\
\hline 22. Roblin & $51 \cdot 20$ & $101 \cdot 45$ & 46 & 58 & 100 \\
\hline 23. Yorkton* & $51 \cdot 22$ & $102 \cdot 47$ & 56 & 31 & 31 \\
\hline 24. Springside & $51 \cdot 35$ & $102 \cdot 75$ & 15 & 42 & 42 \\
\hline 25. Ebenezer & $51 \cdot 37$ & $102 \cdot 45$ & 345 & 41 & 31 \\
\hline 26. Outlook & $51 \cdot 50$ & 107.05 & 72 & 17 & 49 \\
\hline 27. Good Spirit Lake Park & $51 \cdot 57$ & $102 \cdot 65$ & 20 & 50 & 68 \\
\hline 28. Canora* & $51 \cdot 62$ & $102 \cdot 43$ & 51 & 46 & 30 \\
\hline 29. Harris & $51 \cdot 73$ & $107 \cdot 45$ & 34 & 18 & 21 \\
\hline 30. Preeceville* & 51.97 & $102 \cdot 67$ & 77 & 53 & 29 \\
\hline 31. Biggar & $52 \cdot 07$ & $108 \cdot 00$ & 135 & 23 & 48 \\
\hline 32. Hague & $52 \cdot 50$ & $106 \cdot 42$ & 110 & 21 & 41 \\
\hline
\end{tabular}

* Sites also sampled for electrophoretic variation. 
temperature, and (c) by including several other loci, mostly electrophoretic, lay the foundation for discovering the genetic structure of what appears to be a continuously distributed species. The results should provide an interesting antithesis to the few allozyme studies that have tended to concentrate on acridids of low mobility (Tepper, 1979; Daly et al., 1981; Gill, 1981a; 1981b; 1981c).

\section{MATERIALS AND METHODS}

\section{Collection}

Adult $M$. sanguinipes, scored for visible polymorphisms, were collected between the months of July and August, 1978 to 1984, from 30 different localities in southern Saskatchewan; two localities were in Manitoba (table 1). For electrophoretic analysis, grasshoppers from nine of the sites (marked with an asterisk in the table), situated along a climatic gradient (Richards and Fung, 1969) that extends from the generally hot and dry (summer) short grass prairie in the south-west to the relatively cooler and moister aspen parkland in the north-east, were sampled in 1982; three places were resampled in 1983. Collections were made using a sweep net, usually along roadsides and/or adjacent fields.

\section{Traits}

Animals were scored for two colour traits: hind tibia colour (red allele, $T^{\mathrm{R}}$ dominant to blue allele, $T^{\mathrm{B}}$ ) and hind femoral stripe (orange stripe allele, Ost, dominant to stripeless allele, ost) and for possible electrophoretic variations at the 11 enzyme loci: Ldh (lactate dehydrogenase), Mdh (malate dehydrogenase), G-6pd (glucose-6-phosphate dehydrogenase), Sod (superoxide dismutase), Odh (octanol dehydrogenase), Sdh (sorbitol dehydrogenase), $\alpha$ Gpdh-1 and $\alpha$ Gpdh-2 ( $\alpha$ glycerophosphate dehydrogenase), $\mathrm{Xdh}$ (xanthine dehydrogenase), Gldh (glutamate dehydrogenase), and Me (malic enzyme).

\section{Electrophoresis}

Allozyme patterns were ascertained by vertical polyacrylamide slab gel electrophoresis (Hoefer Scientific Model SE 500). After recording the colour traits, eviscerated flight muscle was homogenised in a 10 per cent sucrose solution. The homogenates were then centrifuged at $3000 \mathrm{rpm}$ for 5 minutes and the supernatant used for elec- trophorsis. A portion of the eviscerated tissue was stored at $-70^{\circ} \mathrm{C}$ for later analysis. Two gel buffer systems were used: (1) $0.375 \mathrm{M}$ tris $\mathrm{HCl}, p \mathrm{H} 8.9$ (for LDH, MDH, G-6PD, ODH, SDH, ODH and SOD) and (2) $0 \cdot 1 \mathrm{M}$ tris borate with $2 \mathrm{mM}$ EDTA ( $p \mathrm{H} \mathrm{8.9)}$ for $\alpha$ GPDH-1, $\alpha$ GPDH-2, XDH, GLDH and ME. A $0.5 \mathrm{M}$ tris glycine $(p \mathrm{H} 8.9)$ running buffer was used throughout. The stains for $\mathrm{XDH}$, G-6PD and SDH were essentially the same as those described by Shaw and Prasad (1970); SOD, ME, $\alpha$ GPDH-2 and ODH were stained (with some slight modifications) according to Ayala et al. (1972); LDH and MDH were stained according to Chapco (1984), $50 \mathrm{mg}$ malic acid substituting for lactic acid in the latter case. Gels were run at 7 per cent acrylamide and electrophoresis performed for $2 \frac{1}{2}$ hours at 250 volts.

\section{Analysis}

Allelic frequencies were estimated by gene counting in the case of the enzyme loci (all alleles proved to be codominant) and in the case of the two colour traits, Hardy-Weinberg equilibrium was assumed and the frequencies of the dominant alleles estimated by taking the square-root of the corresponding recessive phenotypic frequencies and subtracting the values from 1 .

Locations were compared by applying loglikelihood ratio tests or G-tests (Everitt, 1977) to 2 (phenotypes) $\times 32$ (locations) contingency tables in the case of the colour traits and to 2 (common allele versus "other" alleles pooled) $\times 9$ (locations) contingency tables in the case of the electrophoretic traits. Geographical diversity was measured by computing Nei's (1972) genetic identity indices between pairs of samples. G-tests were also applied to multiway tables to evaluate interactions among several variables, e.g., genotype $\times$ location $\times$ year.

Climatic information was obtained (Environment Canada, 1983) for the weather station nearest to each sampled area; in a few cases, values between weather stations were obtained by interpolation. Climatic variables chosen were maximum temperature ( $T_{\max }$, the average daily temperature for the hottest month-always July), minimum temperature $\left(\mathrm{T}_{\min }\right.$, the average daily minimum temperature for the coldest monthalways January) and annual precipitation (Prec, snow and rain combined). Nineteen- to 30-year averages (depending on the weather station) were taken, rather than values for the year in which collections were made. To examine the hypothesis that the incidence of red legged grasshoppers is 
connected to temperature and moisture, the following steps were taken: (1) the data were first examined for clinal patterns with respect to three "positional variables": latitude (Lat), longitude (Long) and elevation (Elev) by multiple regression, (2) one or more principle components were extracted from the correlation matrix of climatic variables in order to try to identify "meaningful" weather components (Newham, 1968), e.g. "aridity", and (3) multiple regression and partial correlation analyses were applied in a manner essentially similar to that of Oakeshott et al. (1980) to see if any of the positional variations could be accounted for by the weather principle components; since temperature and moisture were singled out as possible determinants, step 3 also examined the contributions of $\mathrm{T}_{\max }, \mathrm{T}_{\min }$ and Prec. All cases were weighted by sample size. The analyses presented were performed on untransformed frequencies; essentially the same conclusions were reached using angular transformed data.

\section{RESULTS}

\section{Colour traits}

Frequency estimates of the red tibia allele, $T^{\mathrm{R}}$, and of the orange femoral stripe allele, Ost, are presented in table 1 for each of the 32 collection sites. There is tremendous variation among localities for both traits $(2 \times 32$ contingency table $G$ values are 446.8 and 364.7 for tibia colour and femoral stripe, respectively; $P<0.001$ in both cases). Frequencies of $T^{\mathrm{R}}$ range from 8 per cent at Craik, Saskatchewan to 58 per cent at Roblin, Manitoba, $300 \mathrm{~km}$ away; Ost frequencies range from 21 per cent at Harris to 100 per cent at Roblin, $360 \mathrm{~km}$ away. Frequencies quoted represent years (within 1978-84) for which sample sizes were maximal. Justification for deeming year effects insignificant and con- sequently, for assuming genetic equilibrium (otherwise the method of estimating $T^{\mathrm{R}}$ and $O s t$ frequencies would be invalid) is supported by the analysis of two data subsets. First, in the Rowatt region, neither the red tibia nor the orange stripe phenotypic frequencies varied significantly over six years (1978-1983) of sampling; G-test values for each $2 \times 6$ contingency table are $3.84(P=0.57)$ and $3.98(P=0.55)$, respectively. Second, nine sites situated along the previously mentioned climatic gradient were sampled in 1982 and 1983. Data for each trait arranged in a three-dimensional contingency table, when analysed by a series of G-tests, failed to yield significant phenotype $\times$ location $\times$ year interactions $\left(G_{8 d f}=6.54 ; P=0.59\right.$ and $9.52 ; P=0.30$ for tibia colour and femoral stripe, respectively) and significant phenotype $\times$ year interactions $\left(\mathrm{G}_{\mathrm{Idf}}=1.23 ; \mathrm{P}=0.27\right.$ and 2.84 ; $\mathrm{P}=0.09$ for tibia colour and femoral stripe, respectively). If the two subsets are exemplary, then choosing the "best" years for the full analysis is not expected to produce misleading conclusions.

Before examining data for systematic geographical variation and for association with one or more weather factors, each matrix ( $X$, standardised) of positional variables and climatic variables was diagnosed for possible collinearity problems or ill-conditioning created by nonorthogonality. If severe, collinearity can lead to large variances and covariances for standard least square estimators of regression coefficients (Montgomery and Peck, 1982) and, possible, erroneous inferences (e.g., see Mauriello and Roskowski, 1974). In the present study most variables within each set are significantly correlated (table 2), therefore suggesting possible collinearity problems. Several methods have been proposed for diagnosing the extent of collinearity and for deciding if alternative procedures such as ridge regression, are necessary. Following Montgomery and Peck

Table 2 Correlation matrix for red tibia colour (Tib) and femoral stripe (Fs) phenotypic frequencies, positional variables and weather variąbles obtained for each of 32 sites. "Aridity" is first weather principle component. $\$$

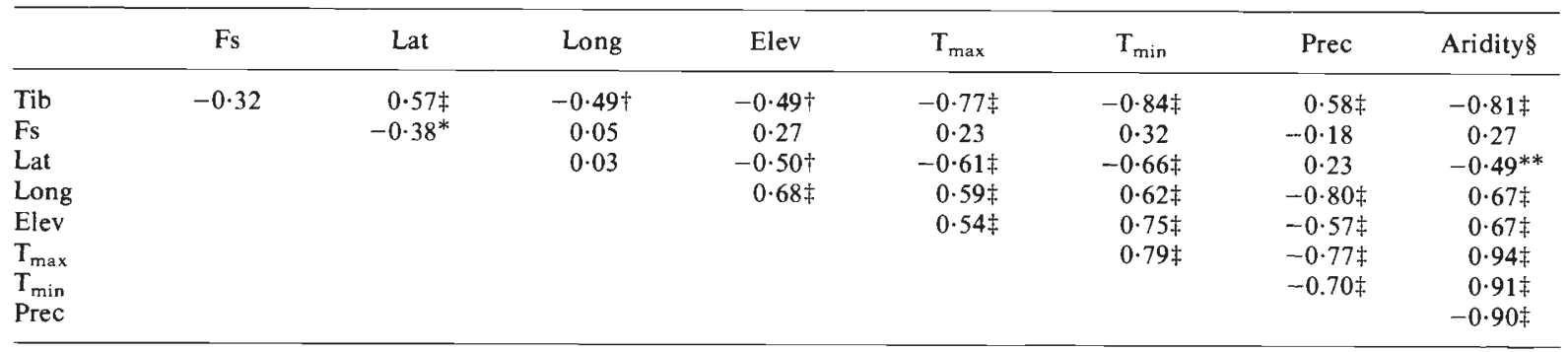

${ }^{*} P<0.05, \dagger P<0.01, \ddagger P<0.001$. Correlations for Tib and Fs are based on weighted samples. $\S$ Aridity-see text. 
(1982), two suggested measures of collinearity (obtained from the correlation matrix, $X^{\prime} X$ ) were computed for each variable set: "condition number", or $K$, and a set of "variance inflation factors", or VIF's (see definitions in reference). For positional variables, $k=13.03$ and the largest VIF $=$ 3.65 , and for the climatic variables, $k=13.45$ and the largest VIF $=3 \cdot 79$; both sets of $k$ 's and VIF's are well below values (100 and 10 , respectively) that would lead to estimation difficulties. Alternative regression methods were, therefore, not required.

Together, latitude, longitude and elevation account for about 81 per cent of the variation in red tibia phenotypic frequency. Each factor "corrected" for the other two is highly significantly contributory (table 3 ). Red tibia is positively associated with latitude and elevation and negatively associated with longitude. The geographic distribution of red tibia phenotypic frequencies is shown in fig. 1; frequencies are low in the south and west and increase in the north-east. A large
Table 3 Multiple (standardised) regression coefficients for tibia colour and orange femoral stripe frequencies with positional variables, latitude, longitude and elevation and with climatic variables, maximum and minimum temperature and precipitation

\begin{tabular}{lcc}
\hline & \multicolumn{2}{c}{ Regression coefficients } \\
\cline { 2 - 3 } & Tibia colour & Femoral stripe \\
\hline Lat & $1.01 \ddagger$ & -0.32 \\
Long & $-1.14 \ddagger$ & 0.15 \\
Elev & $0.65 \ddagger$ & $<0.01$ \\
$\% \mathrm{R}^{2}$ & 80.9 & 16.3 \\
$\mathrm{~T}_{\max }$ & -0.25 & -0.11 \\
$\mathrm{~T}_{\min }$ & $-0.63 \dagger$ & 0.42 \\
Prec $_{\%}$ & $<0.01$ & 0.01 \\
$\mathrm{R}^{2}$ & 72.4 & 10.0
\end{tabular}

$\dagger P<0.01 ; \ddagger P<0.001$.

change evidently occurs (at least in the north-south direction) in a region bounded by Melville-Roblin in the north and Indian Head-Russell in the south. Elevation, of course, is not shown on the map but

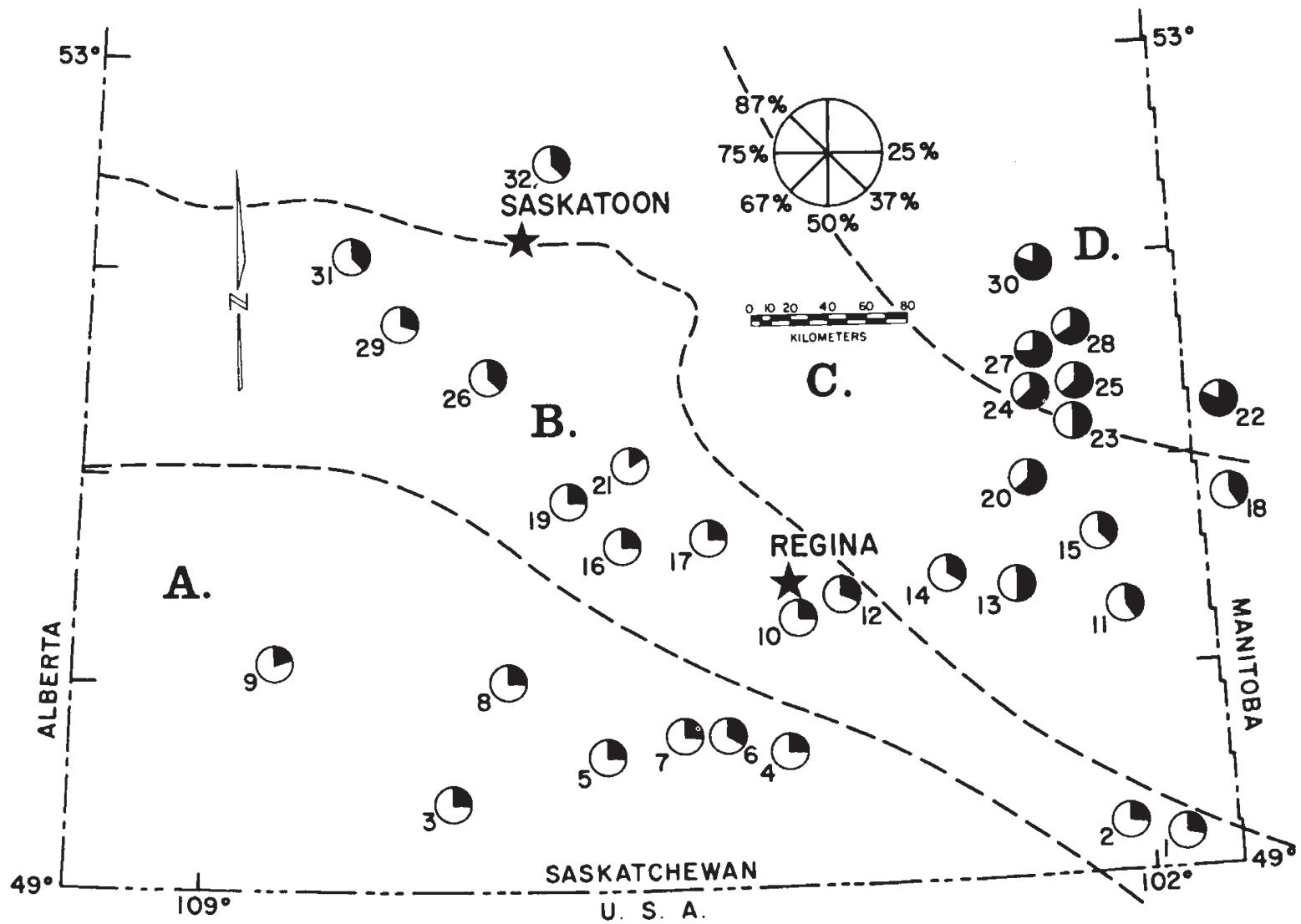

Figure 1 Sample locations (see also table 1) in southern Saskatchewan and adjoining area in Manitoba. Frequency of red tibia phenotype is given by black portion of pie diagram. Major vegetation zones (Rowe, 1983): A, short/mixed prairie; B, mid-grass prairie; C, aspen parkland; D, mixed wood. 
as latitude decreases and longitude increases, elevation increases, thus accounting for the negative sign of the simple correlation with red tibia frequency (table 2). The sign reverses when latitude and longitude are corrected for (table 3 )-would this suggest that $T^{\mathrm{R}}$ frequency is expected to increase with altitude for a narrow ranged mountain? Given the paucity of such topography on the prairies, it is doubtful whether the question can ever be addressed!

A principle component analysis of the correlation matrix of climatic variables reveals that the first component "explains" about 84 per cent of the total climatic variation. From a consideration of the signs and magnitudes of the eigenvector coordinates: $\left(0.37 \mathrm{~T}_{\max }, 0.36 \mathrm{~T}_{\min },-0.36\right.$ Prec $)$, the first component can be regarded as an index of "aridity" with large positive scores in the drier and hotter south-west and large negative scores in the wetter and cooler north-east. The second component accounts for an additional 10 per cent of the variation and has a corresponding eigenvector: $\left(0.13 \mathrm{~T}_{\max }, 1.20 \mathrm{~T}_{\min }, 1.35 \mathrm{Prec}\right)$ with no evident geographical interpretation. In any case, following Jeffers' (see Newham, 1968) suggestion that components with eigenvalues less than one be ignored, the second (and third) component will not be considered further.

Tibia colour frequency and the main principle component are highly negatively correlated (table 2). The extent to which "aridity" accounts for the clinal variations is best seen from an examination of partial correlations between tibia colour and latitude, longitude and elevation, that have been additionally "corrected" for by the first weather principle component (table 4). About 41 per cent and 45 per cent of the latitudinal and longitudinal variation, respectively, is removed by tibia colour's association with "aridity". Significant amounts of variability, however, remain unaccounted for. Only 9 per cent of the elevational variability is accounted for by the weather component. Turning to the climatic factors themselves, each variable is highly correlated with tibia colour (table 2), but only the relationship with minimum temperature is significant as a partial correlation (table 4). About 70 per cent of tibia colour frequency is connected with minimum temperature and this figure increases only slightly ( 72 per cent) if maximum temperature and precipitation are included (table 3 ). The partial correlations listed in the last column of table 4 show that sizeable portions ( 58 per cent and 45 per cent, respectively) of the latitudinal and longitudinal variations are removed by taking minimum temperature into
Table 4 Partial correlations of tibia colour frequencies with positional variables before and after correction for significant climatic factors

\begin{tabular}{|c|c|c|}
\hline \multirow[b]{2}{*}{ Position variable } & \multicolumn{2}{|c|}{ Correlation coefficient } \\
\hline & Before correction & After correction \\
\hline Lat & $0 \cdot 86 \$$ & $\begin{array}{l}0.66 \ddagger(\text { Aridity }) \\
0.56 \dagger\left(\mathrm{T}_{\min }\right)\end{array}$ \\
\hline Long & $-0.82 \ddagger$ & $\begin{array}{l}-0.61 \ddagger(\text { Aridity }) \\
-0.61 \ddagger\left(\mathrm{T}_{\min }\right)\end{array}$ \\
\hline Elev & $0.62 \ddagger$ & $\begin{array}{l}0.59 \dagger \text { (Aridity) } \\
0.61 \ddagger\left(\mathrm{T}_{\text {min }}\right)\end{array}$ \\
\hline
\end{tabular}

$\dagger P<0 \cdot 01, \ddagger P<0 \cdot 001$.

account; nevertheless, the correlations remain highly significant, indicating that minimum temperature (or some factor that is related to minimum temperature) is not the sole important determining factor. Minimum temperature makes a negligible contribution to tibia colour's association with elevation.

Femoral stripe frequencies, unlike those of red tibia, do not exhibit clinal patterns, despite huge interlocational differences. The correlation with latitude is significant at the 5 per cent level (table 2) but disappears with the inclusion of the other two positional variables (table 3 ). None of the correlations involving climatic factors is significant.

\section{Allozymic polymorphism}

Of the 11 enzyme-determining loci examined in 1982-83, $\alpha$ Gpdh-1, Odh, Sod, Sdh, and Gdh were monomorphic for the same allele at all nine sampled locations; Ldh, Mdh, Me, $\alpha$ Gdh-2 and $\mathrm{Xdh}$ displayed some measure of genetic variability. The enzyme, G-6PD, was irresolvable and hence, was excluded from further consideration. Electromorphic frequency estimates are recorded in table 5 for alleles (where "a" corresponds to the "slowest running anodal allele", etc.) at each variant locus within each location. Recorded values for sites, MAN, IND and PRE, are for data obtained in 1982 or 1983 , depending on sample size, the larger being taken. G-tests revealed the absence of any significant inter-year variation. Males and females were pooled since there were no significant differences in allelic frequencies between the sexes at each site. Six alleles were detected for Ldh and three alleles for each of the other loci. With respect to Ldh, alleles a and $d$ represent newly discovered alleles; alleles b, c, e 
Table 5 Allelic frequencies at five variable electrophoretic loci at nine samples sites. $\mathrm{N}$ is sample size. G statistics test for HWE and interlocational variability

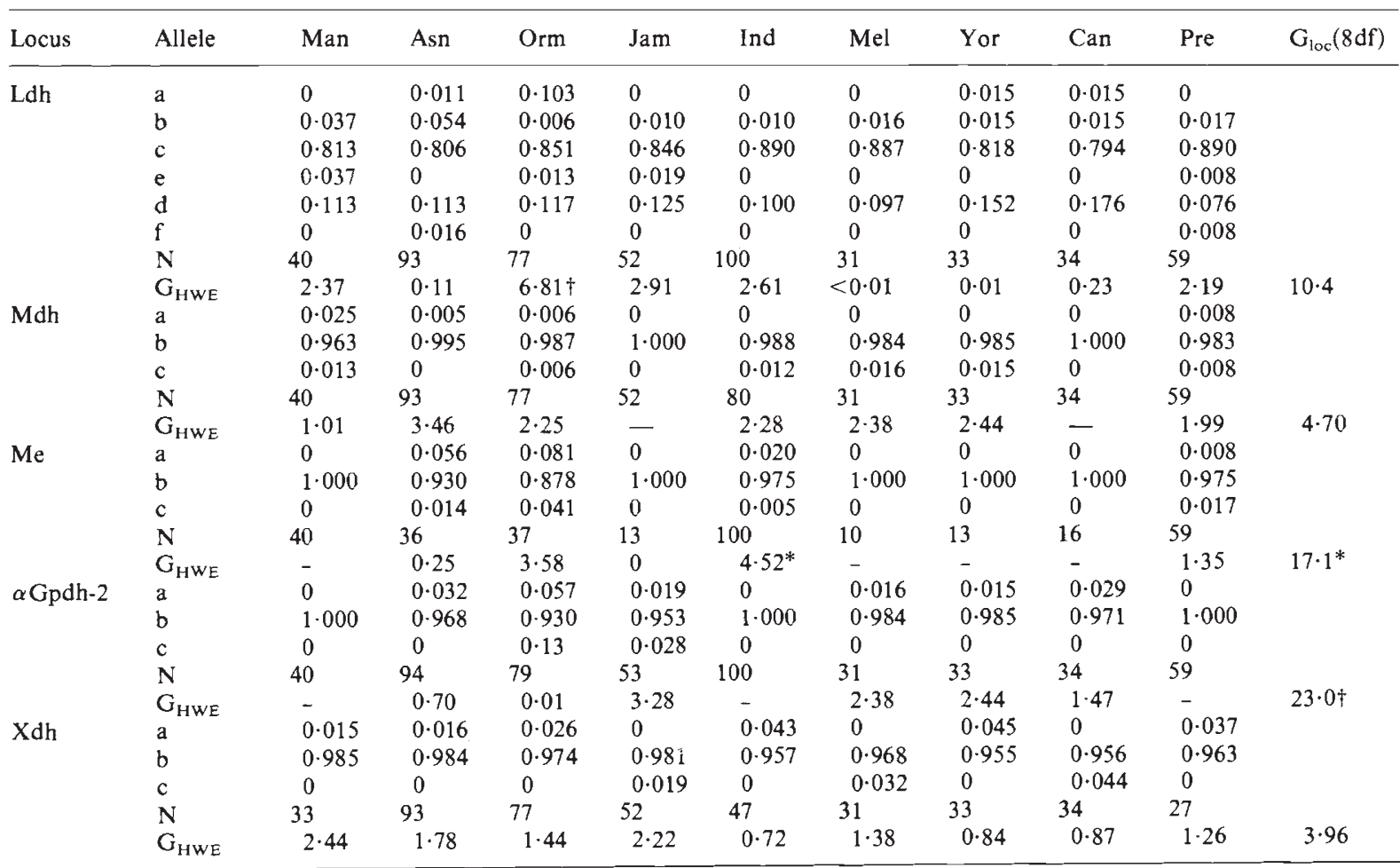

* $P<0.05 ; \dagger P<0.01$.

and $\mathrm{f}$ correspond to $\mathrm{L}^{1}, \mathrm{~L}^{2}, \mathrm{~L}^{3}$ and $\mathrm{L}^{4}$ in Chapco (1983a). To date, the monogenic inheritance of LDH (Chapco, 1984), Me and $\alpha$ GPDH-2 (unpublished results) has been confirmed; $\mathrm{XDH}$ and $\mathrm{MDH}$ are likely also monogenically based, given the rather uncomplicated banding patterns obtained here. Heterozygotes for $\mathrm{Ldh}$ and $\mathrm{Xdh}$ display five bands, which would suggest that the enzymes are tetramers; the remaining three enzymes are probably dimeric, since three bands are obtained for heterozygotes. On the whole, genotypic frequencies (obtained by collapsing each data set to three genotypes) are in agreement with Hardy-Weinberg expectations; two of the 35 calculated G-test values are significant, a finding probably due to chance. Based on the polymorphism criterion that the most common allele should have a frequency of less than 95 per cent, the average frequency of polymorphic loci is 13.3 per cent. This increases substantially to 37.8 per cent if the 99 per cent criterion is used. This discrepancy stems from the fact that the commonest alleles for Mdh, Me, $\alpha$ Gpdh-2 and Xdh "hover" about a frequency of 95 per cent. Based on either criterion,
Ldh is the only gene that is polymorphic in all samples. The average heterozygosity per locus ranges from 3.3 per cent (MEL) to 6.9 per cent (ORM), with a grand average of 4.5 per cent. Per location, the average heterozygosity is highest for Ldh $(27 \cdot 1$ per cent $)$ and lowest for Mdh (2.5 per cent).

Intersite variation, assesses by performing Gtests on all $9 \times 2$ (common allele versus "other" alleles pooled) contingency tables, is not significant for loci, Ldh Mdh and Xdh, but is respectively, significant and highly significant for loci, Me and $\alpha \mathrm{Gpdh}-2$. The biological significance of these data, however, is seen from an examination of the original frequency data (table 5) - the commonest allele is the same across all locations for each enzyme system; there is no instance of a locus in which a different allele is the common one in different sample sites. Moreover, the lack of overall geographical differentiation is reflected in the very high average of 36 genetic identity estimates: $0.9992( \pm 0.0001)$. Grasshoppers sampled from the nine sites behave as if they are part of one large population. 


\section{DISCUSSION}

On a large scale, the present investigation confirms Brooks' (1958) assertion that predominantly redlegged $M$. sanguinipes occur in the eastern parkland of Saskatchewan and predominantly bluelegged forms occur in the grasslands, but until now nothing had been known about areas of transition or the nature of the transition. The results demonstrate that well within the aspen-parkland, an area of mixed grassland and forest (Bird, 1961), that slowly intergrades with the midgrass prairie (Rowe, 1983), a major change in red tibia frequency takes place, at least in a north-south direction and in a north-east-south-west direction (statements about rates of change in a westerly direction cannot be made owing to a lack of samples). For example, phenotypic frequencies in Roblin and Russell, $40 \mathrm{~km}$ south, are 82 per cent and 44 per cent, respectively; also pronounced is the difference between Melville (69 per cent) and Indian Head ( 29 per cent), $75 \mathrm{~km}$ to the south-west. Given the species' capacity for mass movement (see below), the existence of a sharp cline is rather surprising.

In marked contrast, Dearn (1981) reported a smooth latitudinal cline extending over a distance of approximately $1000 \mathrm{~km}$ in the frequency of an inherited dorsal stripe morph in Phaulacridium vitattum. Commonly referred to as "the wingless grasshopper", $P$. vitattum does have a macropterous phase which, according to Dearn (1978), ensures a high degree of gene flow. Disruptive selection coupled with latitudinally varying gene flow from adjacent habitats, is offered as a possible explanation for the trait's distribution. Gill (1979; 1981d), providing several examples of color pattern polymorphisms in a grasshopper of limited mobility, Chorthippus brunneus, favors crypsis as a selection mechanism to account for both large and small morph frequency differences that are found over relatively short distances in Britain. Work on a number of related species sympatric with C. brunneus also led Gill (1981e) to a similar conclusion regarding selective predation. Behaviour and body size differences were considered important in explaining observed sexual dimorphisms (there was no evidence of such dimorphism in tibia colour in $M$. sanguinipes). Schennum (1975) and Schennum and Wiley (1979) investigated geographic variation of a suite of morphometric and colour traits in another grasshopper of low vagility, Arphia conspersa, in several populations in southern Colorado, northern New Mexico and eastern Utah. Although the traits' modes of inheritance have not yet been elucidated (Willey, personal communication), some features can be mentioned for comparison. Most of the traits display geographic variation and in some cases, clinal variation. Differentiation appears to be greater in mountain populations, where gene flow is greatly restricted, than in plains populations. Traits are (partially) correlated with at least one of the factors, latitude, longitude and altitude and in this connection, Schennum (1975) presents a variety of selection arguments, based mostly on ecogeographical rules or their inverses. A large portion of geographical variation, however, remains unaccounted for, about 80 per cent on the average. Of particular interest is the spacial distribution of wing colour morphs which are monomorphic at several population "centres". The centres are separated by fairly narrow intergrade zones within which are found intermediate wing colours. This is guardedly offered along with some historical data as evidence for secondary integradation following allopatric differentiation, at least for this trait.

Perhaps with good reason, but noticeably absent from the above authors' deliberations, are arguments based on genetic drift and gene flow. One has to be impressed with the results of Endler's (1977) gene flow-drift simulations resulting in what appear to be long lasting ( 500 generations in some cases) "stable" (boundaries fluctuate each generation) geographical patterns, some clinal. Conceivably these patterns might correlate temporarily with environmental variables by chance (Johnson et al., 1969). Nevertheless, with respect to $M$. sanguinipes, genetic drift cannot be regarded as an important factor, for the species simply occurs too abundantly (Beirne, 1972). The distribution of the $T^{\mathrm{R}}$ frequencies has therefore, to be discussed in the context of selection and gene flow. Reports of mass movement in this species are legend (see Vickery and Kevan, 1983), but one can only assume that the few mark-recapture studies in which only limited movement was observed (Riegert et al., 1954; Baldwin et al., 1958; Edwards, 1961) were performed either during non-outbreak years or with non-migrating animals. No data on the migratory status (there are reportedly morphometric differences between migratory and nonmigratory $M$. sanguinipes-see Paul and Putnam, 1960; Beirne, 1972) were given. Reports on causes of movement (these usually centre on the availability of food), role of wind, and direction of movement are contradictory (Corkins, 1922; Shotwell, 1930; Parker et al., 1955; Bird et al., 1966; Riegert, 1968; Beirne, 1972; Turnock, 1977); reports on 
direction are assumed to be accurate. Of particular interest is Turnock's statement that there have been easterly movements towards the parkland area and the subsequent establishment of populations (northerly, northwesterly and southerly movements have also been recorded with respect to the study area). How the conclusion of "establishment" was reached without genetic data is enigmatic. What is outstanding, is that despite the movements, which possibly have occurred in several directions and likely at irregular intervals, natural selection has, at least for 30 years (since Brooks' paper in 1958), sustained the general eastern parkland-prairie separation. Intensive sampling over several years would be required to determine the stability and width of the transition zone. Although the nature of the actual selective mechanisms is unknown, the multiple regression and correlation analyses belie the hypothesis that tibia color distribution is connected to moisture and (summer) temperature. This appears to contradict the finding that the first principle component, interpreted as "aridity", accounts for a sizeable proportion of the latitudinal and longitudinal variation, a quantitative result which probably underlies the qualitative observations of earlier workers. The principle components approach, while useful (Johnson et al., 1969), does not identify which of the contained variables is/are directly or indirectly influencing the trait and which variables can be discounted. Of the three climatic variables, minimum temperature is clearly the most contributory (in a statistical sense). One interpretation is that the association is directly causal. In the areas where there is little or no snow cover, soil temperatures can be lethal to eggs (Riegert, 1967). Cold resistant polygenes have been reported in other organisms (e.g. Drosophila pseudoobscura; Parsons, 1973); if such genes are in linkage disequilibrium with the tibia color locus in $M$. sanguinipes populations, the polymorphism might be explained. Pleiotrophy is also a possibility (Wright, 1978) although it is difficult to envisage how there could be differential egg mortality with respect to an adult colour trait. A more likely interpretation is that the association is indirect and that agents such as vegetation or soil factors, that covary with minimum temperature, are causal. The species is capable of exhibiting choices with respect to food (Mulkern et al., 1969) and soil type (Edwards and Epp, 1965); if preferences are genotype-dependent, then blue-legged grasshoppers that find themselves in parkland for instance, simply may not be finding suitable resources. In any case, a substantial portion of the positional variation is unexplained by minimum temperature and therefore, other selective forces need to be explored. Two possibilities are predation and parasitism. It is difficult, however, to see how leg colour could influence the risk of capture although it might be worthwhile to examine stomach contents of known predators such as western meadowlarks (Shotwell, 1930). Bidochka (1984) in a small survey found no evidence of differential parasitic infection with respect to tibia colour even though the incidence of parasites varied geographically (see also Paul and Putman, 1960). In light of the recent discovery that a nondiapause strain of $M$. sanguinipes possesses heteromorphic chromosomes (Zhan et al., 1984), it is possible that the colour polymorphism and, perhaps, distribution, might be caused by linkage disequilibrium between an inversion, say, and the tibia colour locus, a hypothesis to be researched further. The finding of three-way interactions involving body colour, a fourth chromosomal inversion and heat stress in populations of the Australian grasshopper, Austroicetes interioris (Nankivell, 1974) is of particular interest although no attempt was made to explain the geographical distributions.

Selection pressures not at all related to weather or location must be responsible for the distribution of the femoral stripe allele, Ost, despite its close linkage with the $T$ locus (Chapco, 1980b). The two colour loci are neither associated intra- nor interlocationally. Significant geographical concordances among colour pattern genes have been described in Chorthippus brunneus (Gill 1979; 1981d), in which traits combined to produce camouflage effects appropriate for particular habitats. Some associations were reinforced by linkage and epistasis, a result reminiscent of Nabours' (1950 and references therein) extensive work on colourpattern genes in several grouse locust species. Whatever the selection forces are for the Ost locus, they must be powerful enough to withstand the attenuating effects of gene flow.

The level of allozyme polymorphism in $M$. sanguinipes is well within the range of values for most insects (excluding Drosophila; Nevo et al., 1984; Table 6). Heterozygosity, however, is low, as it is in Chorthippus brunneus (Gill, 1981a, $1981 b$ ), resulting from high frequencies of the most common allele (about 98 per cent of all common allele frequencies are greater than $0 \cdot 80$ ). By contrast, two other grasshopper species, Trimerotropis gracilis (Tepper, 1979) and Caledia captiva (Daly et al., 1981) have average heterozygosities more in agreement with the norm. Stochastic forces might account for the low variability, but this is unlikely 
Table 6 Comparison of average heterozygosity (H), polymorphism (P) and genetic identity (I) values in Melanoplus sanguinipes with those of other Orthopterans

\begin{tabular}{|c|c|c|c|c|c|c|}
\hline Species & Site No. & Loci No. & $\% \mathbf{P}$ & $\% \mathrm{H}$ & $\% \mathbf{I}$ & Author(s) \\
\hline \multicolumn{7}{|l|}{ Acridids } \\
\hline M. sanguinipes & 9 & 10 & $37 \cdot 8$ & $4 \cdot 5$ & $99 \cdot 9$ & present \\
\hline Chorthippus brunneus & 42 & 15 & $33 \cdot 0$ & $3 \cdot 2$ & $99 \cdot 9$ & Gill $(1981 a, b)$ \\
\hline Caledia captiva & $2-5$ & 20 & $32 \cdot 0-45 \cdot 0$ & $9 \cdot 0-13 \cdot 5$ & $83 \cdot 5-99 \cdot 0$ & Daly et al. (1981) \\
\hline \multicolumn{7}{|l|}{ Cave crickets } \\
\hline Dolichopoda sp. & 23 & - & - & $11 \cdot 3-28 \cdot 0$ & - & Sbordoni et al. (1981) \\
\hline Troglophilus cavicola & 2 & 17 & $46 \cdot 9$ & $8 \cdot 2$ & $98 \cdot 5$ & Sbordoni et al. (1981) \\
\hline T. andreinii & 3 & 17 & $67 \cdot 0$ & $11 \cdot 3$ & $92 \cdot 8$ & Sbordoni et al (1981) \\
\hline All insects (excluding Drosophila) & - & - & $35 \cdot 0$ & $8 \cdot 9$ & - & Nevo et al. (1984) \\
\hline
\end{tabular}

in C. brunneus and certainly is not the case in $M$. sanguinipes with its large population numbers. Population figures are not provided by Gill but the rather uniform allozyme frequency distribution in C. brunneus (see below) argues against an explanation based on genetic drift. Low genetic variability as predicted by Levins (1968) and demonstrated in several organisms by Bryant (1974), might be imposed by unvarying environments; a likely Orthopteran example (table 6) is Ceuthophilus gracilipes, a cave cricket occupying relatively constant habitats (Cockley et al., 1977) (Sbordoni et al. (1981) attribute differences in heterozygosity in two other cave crickets, Troglophilus cavicola (low) and $T$. andreinii (high), to differences in age of population since establishment by founders). Nevo et al. (1984), in their compendium of $\mathrm{H}$ values and life history traits, invoke Levins' hypothesis in an attempt to explain why species with a low "arid index" have low $\mathrm{H}$ values (at the other extreme, species with high indices have large $\mathrm{H}$ values). Notwithstanding the attractability of this hypothesis, $M$. sanguinipes cannot be seen as an exemplar. The insect is not exclusively an arid species, and environmental variability, at least climatic, is anything but uniform (Environment Canada, 1983). Selection is clearly sustaining high allelic frequencies at each locus, but for reasons as yet unclear.

Selection forces need not be uniform interlocationally to account for the near unity genetic identity values. Gene flow effects may be "strong" enough to overcome tendencies for genetic divergence at the enzyme loci, but as already mentioned, not "strong" enough to attenuate differential selection effects at the visible loci. If gene flow is extensive, one cannot determine whether the selection coefficients are, in fact, homogeneous or spacially variable. In $C$. brunneus, gene flow is low and therefore, the near unity identity values (table 6) imply uniform selection coefficients. In Caledia captiva, four chromosomal taxa are distributed parapatrically in eastern Australia. Identity values for populations within taxa are somewhat lower than those of $M$. sanguinipes and $C$. brunneus, but are considerably higher than values between populations of different taxa. Allozyme divergence is attributed to low gene flow and founder effects rather than selection (Daly et al., 1981).

At one time, Brooks (1958) considered as major and minor "forms" the prairie and parkland populations, and populations in forested areas north of the parkland, separate subspecies; Vickery (1979) regarded the latter designation as premature without further data. This paper demonstrates that with respect to allozyme loci, there is no difference between the major and minor forms; it might, however, be fruitful to examine the more northerly populations, electrophoretically.

Acknowledgements Financial support from the Natural Sciences and Engineering Council of Canada (Grant A-0485 to W. Chapco) and from the Saskatchewan Research Council (Scholarship to M. J. Bidochka) is gratefully acknowledged. We thank Dr E. J. Chapco for comments on the writing.

\section{REFERENCES}

AYALA, F. J., POWELL, J. R., TRACY, M. L., MOURAO, C. A. AND PEREZ-SALAS, S. 1972. Enzyme variability in the Drosophila willistoni group, IV: Genic variations in natural populations of Drosophila willistoni. Genetics, 70, 113-135.

BALDWIN, W. F., RIORDAN, D. F. AND SMITH, R. W. 1958. Note on dispersal of radioactive grasshoppers. Can. Ent., 90, 374-376.

BEIRNE, B. P. 1972. Pest Insects of Annual Crop Plants in Canada. Part V. Orthoptera. pp. 38-56.

BIDOCHKA, M. J. 1984. Genetic variation in natural populations of the migratory grasshopper, Melanoplus sanguinipes. M.Sc. thesis. University of Regina. 
BIRD, R. D. 1961. Ecology of the aspen parkland of western Canada in relation to land use. Canada Department of Agriculture. Res. Br. Publ, 1066, 1-155.

BIRD, R. D., ALLEN, W. AND SMITH, D. S. 1966. The responses of grasshoppers to ecological changes produced by agricultural development in Southwestern Manitoba. Can. Ent., 98, 1191-1205.

BRETT, C. H. 1947. Interrelated effects of food, temperature, and humidity on the development of the lesser migratory grasshopper, Melanoplus mexicanus mexicanus (Saussure) (Orthoptera). Tech. Bull. Okla. Agric. Exp. Stn. No. T-26, pp. 1-50.

BROOKS, A. R. 1958. Acridoidea of Southern Alberta, Saskatchewan and Manitoba (Orthoptera). Can. Ent. Supp., 9, $1-92$.

BRYANT, E. H. 1974. On the adaptive significance of enzyme polymorphisms in relation to environmental variability. Amer. Natur., 108, 1-19.

CHAPCO, w. 1980a. Inheritance of an unusual color variant in the grasshopper Melanoplus sanguinipes. Can. J. Genet. Cytol. 22, 315-318.

CHAPCO, w. 1980b. Genetics of the migratory grasshopper, Melanoplus sanguinipes: Orange stripe and its association with tibia color and red-back genes. Ann. Entomol. Soc. Am. 73, 319-322.

CHAPCO, w. 1983a. The genes, $T^{\mathrm{R}}$, Ost, Pro $^{\mathrm{R}}$ and $L$ in natural populations of Melanoplus sanguinipes. Can. J. Genet. Cytol., 25, 88-92.

CHAPCO, W. 1983b. Genetics and population genetics of grasshoppers and locusts-a bibliography. Bibl. Entomol. Soc. Am., 2, 11-16.

CHAPCO, W. 1984. Inheritance of lactic acid dehydrogenase in Melanoplus sanguinipes (F.) (Orthoptera: Acrididae). Ann. Entomol. Soc. Am. 77, 11-13.

COCKLEY, D. E., GOOCH, J. L. AND WESTON, D. P. 1977. Genic diversity in cave-dwelling crickets (Ceuthophilus gracilipes). Evolution, 31, 313-318.

CORKINS, C. L. 1922. Notes on the migration of Melanoplus atlantis Riley, in Northern North Dakota in 1920. Can. Ent., 54, 1-4.

DALY, J. C., WILKINSON, P. AND SHAW, D. D. 1981. Reproductive isolation in relation to allozymic and chromosomal differentiation in the grasshopper Caledia captiva. Evolution, 35, 1164-1179.

DEARN, J. M. 1978. Polymorphism for wing length and colour pattern in the grasshopper Phaulacridium vittatum (Sjost.). J. Aust. Entomol. Soc. 17, 135-137.

DEARN, J. M. 1981. Latitudinal cline in a colour pattern polymorphism in the Australian grasshopper Phaulacridium vittatum. Heredity, 47, 111-119.

EDWARDS, R. L. 1961. Limited movement of individuals in a population of the migratory grasshopper, Melanoplus bilituratus (Walker) (Acrididae) at Kamloops, British Columbia. Can. Ent., 93, 628-631.

EDWARDS, R. L. AND EPP, H. T. 1965. The influence of soil moisture and soil type on the oviposition behaviour of the migratory grasshopper, Melanoplus sanguinipes (Fabricius). Can. Ent., 97, 401-409.

ENDler, J. A. 1977. Geographic Variation, Specification, and Clines. Princeton University Press. Princeton, New Jersey.

ENVIRONMENT CANADA 1983. Canadian climate normals 1951-1980; Temperature and precipitation-Prairie provinces.

EVERITT, B. S. 1977. The Analysis of Contingency Tables. John Wiley, New York.

GAGE, S. H. AND MUKERJI, M. K. 1977. A perspective of grasshopper population distribution in Saskatchewan and interrelationship with weather. Env. Entomol., 6, 469-479.
GAGE, S. H., MUKERJI, M. K. AND RANDELL, R. L. 1976. A predictive model for seasonal occurrence of three grasshopper species in Saskatchewan. (Orthoptera: Acrididae) Can. Ent., 108, 245-253.

GILL, P. 1979. Colour-pattern variation in relation to habitat in the grasshopper Chorthippus brunneus (Thunberg). Ecol. Entomol., 4, 249-257.

GILL, P. 1981. Heterozygosity estimates in the grasshopper Chorthippus brunneus (Thunberg). Heredity, 46, 269272.

GILl, P. 1981b. Enzyme variation in the grasshopper Chorthippus brunneus (Thunberg). Biol. J. Linn. Soc., 15, 247-258.

GILL, P. $1981 \mathrm{c}$. Allozyme variation in sympatric populations of British grasshoppers-evidence of natural selection. Biol. J. Linn. Soc., 16, 83-91.

GILL, P. 1981d. The genetics of colour-patterns in the grasshopper Chorthippus brunneus. Biol. J. Linn. Soc., 16, 243-259.

GILL, P. 1981e. Colour-patterns and ecology of British grasshoppers. Acrida, 10, 145-158.

GURNEY, A. B. 1962. On the name of the migratory grasshopper of the United States and Canada, Melanoplus sanguinipes (F.) (Orthoptera: Acrididae). Proc. Biol. Soc. Wash. 75, 189-192.

GURNEY, A. B. AND BROOKS, A. R. 1959. Grasshoppers of the Mexicanus group, Genus Melanoplus (Orthoptera: Acrididae). Proc. U.S. Natl. Mus. 110, 1-93.

heBARD, M. 1925. The Orthoptera of South Dakota. Proc. Acad. Nat. Sci. Philadelphia, 77, 33-155.

JOHNSON, C. G. 1969 Migration and Dispersal of Insects by Flight. Methuen, London.

JOHNSON, F. M., SCHAFFER, H. E., GILLASPY, J. E. AND ROCK WOOD, E. S. 1969. Isozyme genotype-environmental relationships in natural populations of the harvester ant, Pogonomyrmex barbatus from Texas. Biochem. Genet., 3, $429-450$

KING, R. L. AND SLIFER, E. H. 1955. The inheritance of red and blue hind tibiae in the lesser migratory grasshopper. J. Heredity, 56, 7-10.

LEVINS, R. 1968. Evolution in Changing Environments. Princeton University Press, Princeton, N.J.

MAURIELLO, D. AND ROSKOWSKI, J. P. 1974. A reanalysis of Vuilleumier's data. Amer. Natur., 108, 711-714.

MONTGOMERY, D. C. AND PECK, A. 1982. Introduction to Linear Regression Analysis. Wiley, New York.

MULKERN, G. B., PRUESS, K. P., KNUTSON, H., HAGEN, A. F., CAMPBELL, J. B. AND LAMBKY, J. D. 1969. Food habits and preferences of grassland grasshoppers. Bull. N. Dakota Agr. Exp. Sta., 481, 1-48.

NABOURS, R. K. 1950. Cytogenetics of the grouse locust Apotettix eurycaphalus Hancock. Kansas. Agric. Exp. Stn. Tech. Bull., 67, 1-116.

NANKIVELL, R. N. 1974. Interactions between inversion polymorphisms and the colour pattern polymorphism in the grasshopper Austroicetes interioris (White \& Key). Acrida, 3, 93-111.

NEI, M. 1975. Molecular Population Genetics and Evolution. North-Holland Publishing Co. Amsterdam.

NEVO, E., BEILES, A. AND BEN-SHLOMO, R. 1984. The evolutionary significance of genetic diversity: ecological, demographic and life history correlates. In Levin $\mathrm{S}$. (ed.) Lecture Notes in Biomathematics 53: Evolutionary Dynamics of Genetic Diversity. Springer-Verlag, New York.

NEWHAM, R. M. 1968. A classification of climate by principle component analysis and its relationship to tree species distribution. Forest Science, 14, 254-264. 
OAKESHOTT, J. G., GIBSON, J. B., ANDERSON, P. R., KNIBB, W. R., ANDERSON, D. G. AND CHAMBERS, G. K. Alcohol dehydrogenase and glycerol-3-phosphate dehydrogenase clines in Drosophila melanogaster on different continents. Evolution, 36, 86-96.

PARKER, J. R., NEWTON, R. C. AND SHOTWELL, R. L. 1955. Observations of mass flights and other activities of the migratory grasshopper. U.S. Dept. Agr. Tech. Bull. 1109, $46 \mathrm{pp}$.

PARSONS, P. A. 1973. Behavioural and Ecological Genetics. A Study in Drosophila. Clarendon Press, Oxford.

PAUL, L. C. AND PUTNAM, L. G. 1960. Morphometrics, parasites and predators of migrant Melanoplus bilituratus (Wlk.) (Orthoptera: Acrididae) in Saskatchewan in 1940. Can. Ent., 92, 488-493.

RICHARDS, J. H. AND FUNG, K. I. 1969. Atlas of Saskatchewan. University of Saskatchewan, Saskatoon.

RIEGERT, P. W. 1967. Associaton of subzero temperatures, snow cover, and winter mortality of grasshopper eggs in Saskatchewan. Can. Ent. 99, 1000-1003.

RIEGERT, P. W. 1968. A history of grasshopper abundance surveys and forecasts of outbreaks in Saskatchewan. Memoirs of the Ent. Soc. Canada, No. 52. pp. 99.

RIEGERT, P. W., FULLER, R. A. AND PUTNAM, L. G. 1954. Studies in dispersal of grasshoppers (Acrididae) tagged with Phosphorus-32. Can. Ent., 86, 223-232.

ROFFEY, J. 1970. The effects of changing land use on locusts and grasshoppers. Proc. 1st. Study Conf. Current and Future Problems of Acridology, London.

ROWE, J. S. 1983. Landscapes: A Guide to the Land Forms and Ecology of Southern Saskatchewan. Reference Manual. Sask. Env. Public Information and Education Branch. Regina, Saskatchewan.
SBORDONI, V., ALLEGRUCCI, G., CACCONE, A., CESARONI, D. SBORDONI, M. C. AND DE MATTHAEIS, E. 1981. Genetic variability and divergence in cave populations of Troglophilus cavicola and T. andreinii (Orthoptera, Rhaphidophoridae). Evolution, 35, 226-233.

SCHENNUM, W. E. 1975. A Geographical Analysis of Quantitative Morphological Variation in the Grashopper Arphia conspera. Ph.D. Dissertation. University of Illinois, Chicago.

SCHENNUM, W. E. AND WILLEY, R. B. 1979. A geographical analysis of quantitative morphological variation in the grasshopper Arphia conspera. Evolution, 33, 64-84.

SHAW, C. R. AND PRASAD, R. 1970. Starch gel electrophoresis of enzymes-A compilation of recipes. Biochem. Genet., 4 , 297-320.

SHOTWELL, R. L. 1930. A study of the lesser migratory grasshopper. U.S. Dept. Agric. Tech. Bull., 190, 1-34.

TEPPER, C. S. 1979. Chromosomal and Electromorphic Variation in the Grasshopper Trimerotropis gracilis gracilis. M.S. Thesis. San Diego State University.

TURNOCK, w. J. 1977. Adaptability and stability of insect pest poulations in prairie agricultural ecosystems. In Kulman, H. M. and Chiang, H. C. (eds.) Insect Ecology Papers Presented in the A. C. Hodson Lectures. U. Minn. Agr. Exp. Stn. Tech. Bull., 310, 89-101.

VICKERY, V. R. AND McE, KEVAN, D. K. 1983. A Monograph of the Orthopteroid Insects of Canada and Adjacent Regions. Lyman Entomol. Mus. and Res. Lab Memoir No. 13. Vol. II

VICKERY, V. R. 1979. Notes on some Canadian Acrididae (Orthoptera). Can. Ent., 111, 699-702.

WRIGHT, S.. 1978. Variability Within and Among Natural Populations. Vol. 4. Univ. of Illinois, Chicago Press, Chicago.

ZHAN, T. S., PATHAK, S. AND LIANG, J. C. 1984. Induction of G-bands in the chromosomes of Melanoplus sanguinipes (Orthoptera, Acrididae). Can. J. Genet. Cytol., 26, 354-359. 